\title{
INVESTIGATING BANKING HOUSEHOLDS' DEPOSITS USING VECTOR AUTOREGRESSIVE MODEL VAR
}

\author{
Adina Elena Dănuleţiu ${ }^{1}$ \\ Iulia Cristina Iuga ${ }^{2}$ \\ Adela Socol ${ }^{3}$
}

\begin{abstract}
Nowadays, settling a proper and adequate relationship with the customers became a concern of the banks, that have to "back to basics" and obtain the trust when interact with customers. Banking customers represented by the population's householders matter in banks' financing if we retain that in the last year, the household deposits represented $29.2 \%$ of total liabilities of credit institutions active in Romania. This paper argues that in order to study the influence factors that affect the banking customers' behavior, it is important to consider the saving process of banking customers as an exogenous dynamic phenomenon, while the study does not deny, but it not approached another face of thinks - the endogenous influences. The paper examines if there exist any long-run relationships between deposits made by the population's householders and their behavior influenced by the interest rate on the deposits set up in banks by householders, the unemployment rate, the monthly net wages in the economy and the consumer price index. We provide an unrestricted Vector Autoregression Model (VAR) in order to investigate the relationship between variables mentioned above, using the data set on Romanian banking system, which covers the period January 2007 - December 2012. Our research confirms the impact that the interest rate on deposits has on the banking customers' behavior, mirrored in the deposits made with active banks in Romania by the population's householders.
\end{abstract}

Keywords: banking customers' behavior, deposits, Vector Autoregressive Model, impulse response, exogenous factors

JEL Codes: D12, C58, G21

\section{Introduction}

Obtaining an adequate level and structure of banking deposits represents a major challenge for commercial banks, in their essays to equilibrate the financing sources with the placements. Importance of deposits for banks is well known and the segment of customers represented by the population's householders retains nowadays banks' attention, because of their unexploited potential and reduced costs of these attracted financing sources.

We developed this paper in tempting to find out what influences the volume of deposits made with active banks in Romania by the population's householders. Our considerations straightened to variables that can affect the banking customers' behavior. Understanding banking customer behavior represents a favorite theme of the banks' actual concerns and aspires to be an important topic in the scientific economic research. Banks have to take care of customers'

\footnotetext{
1 “1 Decembrie 1918” University of Alba Iulia, Alba Iulia, 11-13, Nicolae Iorga street, Romania, email: adina.danuletiu@gmail.com

2 "1 Decembrie 1918" University of Alba Iulia, Alba Iulia, 11-13, Nicolae Iorga street, Romania, email: iuga_iulia@yahoo.com

3 "1 Decembrie 1918" University of Alba Iulia, Alba Iulia, 11-13, Nicolae Iorga street, Romania, email: adelasocol@yahoo.com
} 
expectations and at the same time banks have to maintain the relation with customers in the profitable terms for both parts. The contemporary financial crisis modifies the customers' perceptions towards their banks, which are in competition to offer quality services and a personal relationship with their customers. Often, in this race, banks "forget" to clearly and transparent explain to customers the banking complex product and prefer the classical understandable banking language and some printed documents.

Firstly, our attention directed to identify the potential factors that can influence the banking customers' behavior (customers represented by the population's householders) in the saving process and we grouped into endogenous and exogenous elements. The relationship between customers and banks are affect by the endogenous factors, such banks' politics and actions (e.g. Concerning to the levels of interests internal rates of deposits and the specific clauses of deposits) or customers' expectations and perceptions referring to the banks.

We developed the studied on the exogenous factors that would influence the volumes of banking deposits of population's householders and considered five variables in our investigation: deposits made with active banks in Romania by the population's householders, interest rate on the deposits set up in banks by householders, unemployment rate, monthly net wages in the economy and consumer price index. Based on these variable, we developed a model, an unrestricted Vector Autoregression Model (VAR) in order to investigate the relationship between variables mentioned above, using the data set on Romanian banking system, that covers the period January 2007 December 2012.

The main purpose of our study is to evaluate the effects of the different shocks on the VAR DDEP (deposits made with active banks in Romania by the population's householders) system's variables, considering that each variable is influenced by the own impulse and also it is influenced by the impulses of the other variables. Studied variables present features that permit VAR approach, through we aim the following types of results: impulse response function and variance decomposition.

The paper is organized as follow: The first section of the paper reviews the literature and regulations on banking deposits and their influence factors. The second section presents the econometrical model, finding and discussions, focusing on interpreting Vector Autoregression. The last section concluded with conclusions, limits of the research and future approaches.

\section{Literature review}

The importance of the household deposits in the Romanian banking system generated the article's research challenge in order to identify the factors that could affect the deposits made by the population's householders and their behavior. Recent manifestation of the international financial crises brings into prominence the importance of the banking financing sources and moves the centre of interest from financial markets towards the classical types of funds, like customers' deposits. Worsening of the foreign financing influenced the Romanian banks' situation in their essays to attract fund for financing of the activity and banks direct towards the alternative financing sources represented by the domestic deposit. Public data issued by the National Bank of Romania in the last years proved the Romanian banking system's dependency of household deposits that increased in terms of percent of total liabilities of credit institutions from 24.4 percent in December 2008 to 31.8 percent in August 2013 (National Bank of Romania, Stability Financial Report 2013, p. 36).

The analysis of the factors that could affect the behavior of the Romanian population's householders has not been conducted through the identified specialized papers and in these conditions, our paper intends to fill a gap in the field. We identify only the studies that used Vector Autoregressive VAR method to investigate another economic Romanian economic phenomena.

Some authors utilized the Bayesian VAR Vector Autoregressive approach to study the monetary policy transmission mechanism in Romania between 1998-2012 and found that the 
adjustment procedure of loans and deposits interest rates (Roșoiu and Roșoiu, 2014). Vector Autoregressive VAR model with five endogenous variable was developed by Ciurila, in order to analyse the impact in the exchange rate on inflation, using as variables: the first difference of the $\log$ RON/EUR exchange rate which represents the depreciation/appreciation of the domestic currency, the inflation based on the Producer Price Index (PPI), the CORE1 inflation and the first difference of the log broad money aggregate (Ciurila, 2007). The impact of short-term interest rates upon industrial production, loan to deposit to deposit ratio for the banking system, stock prices and exchange rate was studied by Cocriș and Nucu (Cocriș and Nucu, 2013). A paper belonged to Spulbăr and Nițoi (Spulbăr and Nițoi, 2013) used the Bayesian Vector Autoregression model to analyse the monetary policy in Romania in line with the interest rate channel, the inflation and the unemployment rate. Mutașcu and Fleischer investigated the relationship between economic growth and globalization using the Unrestricted Vector Model during 1972-2006 and they found that if countries tend to maximize the economic growth, they have to globalize more (Mutașcu and Fleischer, 2011). VAR Vector Autoregressive model wad developed for short-time prognoses related to the main prices in economy - consumer price index, exchange rate, monthly wage and interest rate (Pecican, 2010).

Our research adheres to dynamic modeling of the banking households' deposits volumes and we try to link our approach with the previous relevant studies in the domain. We identified in the literature several studies that analyse the banks' financing sources and the costs and implications. Banks' deposit is considered by Holod and Lewis (Holod and Lewis, 2011) an intermediate product that is an output from the first stage of the bank production process and is an input to the second stage. The authors developed a Data Envelopment Analysis (DEA) model of bank efficiency that treats deposits as neither an input nor an output and proved that the effect of the amount of deposits on the overall bank efficiency depends on the efficiency at both stages of the bank production process. Classical statistical models of deposit volumes are based on the variables doubtful to influence the deposit volumes. Deposits are modelled like a function of the current deposit rate, the current market rate, recent deposit balance levels, and a measure of nominal income which is an interpolation of national data and regional data for the county where the bank is situated (O'Brien, 2000, cited by Nyström, 2008). An interesting modern perspective on the deposit belongs to Nyström (Nyström, 2008) that developed a framework for the modeling and valuation of deposits, through modeling of deposit rates and deposit volumes. We are interested into modeling the deposit volumes and remarked that the mentioned author build a model based on the behavior of the individual customers which are considered rational, but their rationality differ from one another by their specific strikes whereas differences between subjective strikes capture the individual costs associated with decisions of the customer. A comprehensive analysis of the specialized papers belongs to Koziol and Lawrenz (Koziol and Lawrenz, 2009) that developed a model which allows the banks to actively adjust their deposit volumes in a continuous-time model. The authors showed that the higher level of deposit volume permits to the bank to invest more into its valuable assets, while a higher deposit volume implies that the present value of restructuring costs rises.

\section{Research Methodology and Hypotheses Development}

The paper adheres to interpretive and qualitative research methodologies in the economic science, through studying the literature in the area and using descriptive or conceptual techniques. Also, the study is based on the traditional econometric methodology, through the development of one model in order to investigate the evolution of domestic banking deposits. Choosing the Vector Autoregressive VAR method in the model's development is justified through the character of our investigation, which refers to examination of the dynamics of the deposits made with active banks in Romania by the population's householders. Starting with ' 80 the vector autoregressive VAR models demonstrated their adequacy in the economic analysis of the time series data (Sims,1980). 
We consider five variables in our investigation: The deposits made with active banks in Romania by the population's householders (DEP), The interest rate on the deposits set up in banks by householders (INT), Consumer price index (CPI), Unemployment rate (UN) and Monthly net Wages in the economy (W).

We have performed an unrestricted Vector Autoregression Model (VAR) in order to investigate the relationship: "DDEP DDINT DCPI DDUN DW", accomplishing the following steps: defining the variables and collect the data, process the data using Eviews support and analyze the results.

Firstly, we defined the mentioned variables and terms and realized their descriptive statistics in the Table no. 1. The first variable, the deposits made with active banks in Romania by the population's householders (DEP), are time deposits in Lei (which are made of time deposits in lei: for a term of one year; for a term of more than one year) granted by the commercial banks from Romania to householders. To grant and use bank deposits is the main function of banks in general. Bank deposits are the main form of mobilizing capital and savings that are temporarily available. Through households it understanding according the legal norms, physical persons, or groups of physical persons who consume goods and services, who share the same home, use jointly a part or the whole income and patrimony, consume jointly goods and services and eventually, produce nonfinancial goods and/or services for their exclusive use.

The second variable represents the interest rate on the deposits set up in banks by householders (INT). Ever since January 2007, the average interest rates of deposits and the average interest rates of new deposit contracts are determined according to the methodology established by the CE Regulation no. 63/2002 of the European Central Bank of December 20 $0^{\text {th }} 2001$ on the statistics relating to the interest rates used by monetary financial institutions for the deposits set up by households and non-financial companies and the loans they were granted (ECB/2001/18), modified by CE Regulation no. 290/2009 of the European Central Bank of March $31^{\text {st }} 2009$ $(\mathrm{ECB} / 2009 / 7)$. The average interest rates are computed as the arithmetic average of the annual rates of the interest, weighted by the balance at the end of the interest reference month, respectively the value of new deposit contracts of the month of reference.

The third variable the consumer price index (CPI) measures changes in the price level of a market basket and of services used by a certain population in a given period of time (current period), as compared to a previous period (the reference period). The Consumer price index (CPI) is meant to measure changes in the dynamic of price levels for the products and services purchased by households throughout the country. The CPI is a monthly index and is calculated only for products and services that are directly used by the population, the following categories being excluded: homemade goods and services, expenditures in the form of investments and accumulation, interests paid for credits, insurance installments, fines, taxes etc., as well as expenditures related to household works and production (agriculture etc.). The CPI measures the general tendency of evolution for consumer prices. The Methodology for calculating the CPI corresponds to the recommendations of the international institutions, especially to those presented in the manual Consumer Price Indexes, issued by The International Labor Organization (ILO), The International Monetary Fund (IMF), The Organization for Economic Co-operation and Development (OECD), The Statistical Office of the European Communities (SOEC), The World Bank (WB). The IPC is calculated based on the structure of household expenditures and prices. Consumer price indexes (CPI) are considered amongst the fundamental macroeconomic indexes. Aside from their important role in implementing the monetary policy and in the economic analysis in general, these indexes are also used for other purposes, such as evaluating the variation of the purchasing power of incomes, wage negotiations, indexing contract prices.

The fourth variable is the unemployment rate (UN). Unemployment is an economic phenomenon that is directly related to economic and financial crises. This phenomenon is prompted 
due to the discrepancy between the demand and offer of jobs. The International Labour Organization definition of the unemployment rate is the most widely used labour market indicator because of its international comparability and relatively timely availability. Besides the unemployment rate, indicators such as employment and job vacancies also give useful insights into labour market developments (Eurostat, 2012). The unemployment rate is an important indicator with both social and economic dimensions. The unemployment rate is calculated as a percentage between unemployed and labour force. The registered unemployment rate is determined by relating the total number of registered unemployed individuals to the active civilian population. The source of the data for the number of registered unemployed individuals and the registered unemployment rate is the National Agency for Occupying Workforce in Romania. According to the international definition, unemployed individuals (according to the Bureau of International Labour - BIL), are persons between 15 and 74 years of age which fulfill simultaneously these conditions: do not have a job; are available to start a job within two weeks; have been actively seeking for a job for the last four weeks. Unemployment rate (UN) represents the weight of unemployed individuals, according to the international definition (according to the BIL), in the active population. Monthly net Wages in the economy $(\mathrm{W})$ represent the numbers of employee multiplied by the average monthly net income in the economy.

The fifth variable, the average monthly net income in the economy, represents the ratio between the paid amount to the employees by the economic agents in a month of reference, irrespective of the period for which they are paid and the average number of employees. The average number of employees represents a simple arithmetic means calculated on daily number of employees in that specific month (only the employees that were actually paid that particular month are to be taken into consideration. We do not consider: employees who are on leave without pay, on strike, seconded to work abroad and those whose work agreement was suspended).

We analyze the data set covers the period January 2007 - December 2012 with reference to Romania, with monthly frequency (72 observations). The data was obtained from: National Bank of Romania, Monthly Economic Bulletins, National Statistical Institute of Romania, Labour Office. Descriptive statistics of all variables are given in Table no. 1.

The average value of deposits for the analyzed period is 41,683.68 million Lei, with a variation between 20,891.30 million Lei (reported in January 2007) and a maximum of 61,773.10 (reported in May 2012). Inside the set of considered data, the values between the set average and the set maximum are more numerous than those in the first half of the variation interval of the researched index.

Using the Eviews support, we determined the variation interval for the interest rate, and we established that the value fits between $5.31 \%$ in 2012 and $14.08 \%$ in 2009 . The average value for this index for the entire analyzed period is $7.94 \%$. The above table shows that the statistical tests applied to the data sets related to the five indexes are not identical. Based on these findings, we can assert that there is a rather low interdependence between these factors.

In our research the hypotheses are:

H1: The level of DEP is growing as the interest rate on the deposit set up in banks by householders is increasing (and vice-versa)

$\mathrm{H} 2$ : The level of DEP is growing as the Consumer price index is decreasing (and vice-versa)

H3: The level of DEP is growing as the Unemployment rate is decreasing (and vice-versa)

H4: The level of DEP is growing as the Monthly net Wages in the economy is increasing (and viceversa) 
Table no. 1

The 'sings' of the hypothesis' work relations

\begin{tabular}{|l|l|l|}
\hline The statement & Variable and ‘tendency sign' & Variable and ‘tendency sign' \\
\hline H1 & DEP + or - & INT + or - \\
\hline H2 & DEP + or - & CPI - or + \\
\hline H3 & DEP + or - & UN - or + \\
\hline H4 & DEP + or - & W + or - \\
\hline
\end{tabular}

The first statement's case relives that the relationship between the population's householders deposit and the interest rate on the deposit set up in banks by householders have the same sign (if DEP grows, INT increase and vice-versa).

The second statement's case consider that the connection DEP and CPI have contrary sign (if DEP grows, CPI decrease and vice-versa).

The third statement's case relives that the connection DEP and UN have contrary sign (if DEP grows, UN decrease and vice-versa).

The forth statement's case relives that the connection DEP and W have contrary sign (if DEP grows, $\mathrm{W}$ decrease and vice-versa).

To conclude, aside from the four indexes (INT, CPI, UN, W), there are other factors as well, mainly non-economic in nature, which influence the volume of deposits. For variables wages and unemployment rate we proceed to seasonally adjust and for variables deposits and seasonally adjust wages we proceed to logarithms. The new variables are LDEP, LW and UN_SA.

The next step we need to check unit root tests of variables.

Available literature suggests that majority of the time series macroeconomic data are nonstationary or have a unit root (Nelson and Plosser, 1982). A non-stationary series according to Harvey (Harvey, 1990) is one where the moments (mean, variance and covariance) of the distribution from which series observations were drawn are time-variant; they depend on the point in time at which the observations were realized. A combination of variables that is non-stationary may lead to spurious regression results. Therefore, it was important to test for the stationarity of the variables to be employed for the study. One way to remedy non-stationary is by differencing the variables to reverse them to stationary variables in order to obtain consistent parameter estimates, though this may lead to a loss of long-run properties of the data (Gujarati, 2001).

Table no. 2

Descriptive statistics of the variables

\begin{tabular}{|l|l|l|l|l|l|}
\hline Item & DEP & INT & CPI & UN & W \\
\hline Mean & 41683.68 & 0.079461 & 0.055901 & 0.054554 & 6029.079 \\
\hline Median & 43832.85 & 0.070300 & 0.051300 & 0.050900 & 6147.406 \\
\hline Maximum & 61773.10 & 0.140800 & 0.090400 & 0.084000 & 7316.785 \\
\hline Minimum & 20891.30 & 0.053100 & 0.017900 & 0.038000 & 4265.946 \\
\hline Std. Dev. & 14298.48 & 0.023348 & 0.019673 & 0.013434 & 623.3518 \\
\hline Skewness & -0.090629 & 1.272926 & -0.033582 & 0.646842 & -0.922063 \\
\hline Kurtosis & 1.530352 & 3.670823 & 1.872157 & 2.262138 & 3.542550 \\
\hline Jarque-Bera & 6.578161 & 20.79410 & 3.829622 & 6.654170 & 11.08549 \\
\hline Probability & 0.037288 & 0.000031 & 0.147370 & 0.035898 & 0.003916 \\
\hline Sum & 3001225. & 5.721200 & 4.024900 & 3.927900 & 434093.7 \\
\hline Sum Sq. Dev. & $1.45 \mathrm{E}+10$ & 0.038704 & 0.027480 & 0.012813 & 27588292 \\
\hline Observations & 72 & 72 & 72 & 72 & 72 \\
\hline
\end{tabular}

Source: authorial calculations 
Notes: $\mathrm{DEP}=$ the deposits made with active banks in Romania by the population's householders; $\mathrm{INT}=$ The interest rate on the deposits set up in banks by householders, $\mathrm{CPI}=$ Consumer price index, $\mathrm{UN}=$ Unemployment rate; $\mathrm{W}=$ Monthly net Wages in the economy.

Unit root tests of variables are based on Augmented Dickey-Fuller (ADF) and PhillipsPerron (PP) test. The results, suggest that all series are not stationary. The series LDEP, LW, CPI are I(1) and series INT and UN_SA are I(2). According to VAR methodologies all the variables should be stationary so we proceed to make the series stationary. The series which are I(1) we $1^{\text {st }}$ differenced to became $\mathrm{I}(0)$ and the series which are $\mathrm{I}(2)$ we 2 rd differenced to became $\mathrm{I}(0)$. Our series became DDEP DDINT DCPI DDUN DW.

We have performed an unrestricted Vector Autoregression Model (VAR) in order to investigate the relationship: "DDEP DDINT DCPI DDUN DW". We choose the VAR model, because it is proper to be applied for the endogenous variables in a multi-equation system of the variables. The model uses one equation for each variable as dependent variable and for each equation there are lagged values of all the included variables as dependent variables, including the dependent variable itself. The model can establish in a reduced form, if there are no contemporaneous variables included as explanatory, right-hand side variables. In this case, all the equations have the same form, since they share the same right-hand side variables. From the VAR model, we expect to find how shocks (influences) are transmitted from an variable to another.

As Cromwell et al.(1994) have indicated, such a model is commonly used for forecasting systems of interrelated time series and for analyzing the dynamic impact of random disturbances on the system of variables. In vector autoregression models some variables are treated as endogenous and some as exogenous or predetermined (exogenous plus lagged endogenous). For our approach, the five variables are treated as exogenous variables.

Table no. 3

\section{VAR Lag Order Selection Criteria}

Endogenous variables: DDEP DDINT DDUN DW DCPI

Exogenous variables: C, Sample: 2007M01 2012M12, Included observations: 64

\begin{tabular}{lllllll}
\hline \hline Lag & LogL & LR & FPE & AIC & SC & HQ \\
\hline \hline 0 & 1181.365 & NA & $7.45 \mathrm{e}-23$ & -36.76139 & -36.59273 & -36.69495 \\
1 & 1237.095 & 101.0119 & $2.86 \mathrm{e}-23^{*}$ & $-37.72173^{*}$ & $-36.70975^{*}$ & $-37.32306^{*}$ \\
2 & 1257.254 & 33.38767 & $3.38 \mathrm{e}-23$ & -37.57043 & -35.71514 & -36.83954 \\
3 & 1283.062 & $38.71146^{*}$ & $3.42 \mathrm{e}-23$ & -37.59567 & -34.89707 & -36.53256 \\
4 & 1293.247 & 13.68687 & $5.83 \mathrm{e}-23$ & -37.13272 & -33.59080 & -35.73738 \\
5 & 1320.803 & 32.72294 & $6.09 \mathrm{e}-23$ & -37.21260 & -32.82737 & -35.48504 \\
6 & 1343.226 & 23.12324 & $8.01 \mathrm{e}-23$ & -37.13206 & -31.90351 & -35.07227 \\
\hline \hline
\end{tabular}

Source: authorial calculations

* indicates lag order selected by the criterion

LR: sequential modified LR test statistic (each test at 5\% level)

FPE: Final prediction error

The VAR provides a useful framework for the investigation of both long-run (cointegration) relationships and short-run dynamics of the variables in the system. The next main steps we need to follow in order to perform the econometric analysis are: joint lag selection and VAR, stability test, and residuals tests. Joint lag selection and VAR illustrate the joint lag selection criteria and the VAR analysis. For the selection of the joint lags we considered the VAR Lag Order Selection 
Criteria (Table no. 2). All the criteria (FPE, AIC, SC and HQ) except LR recommended a joint lag 1 .

VAR Lag Exclusion Wald Tests

Table no. 4

Sample: 2007M01 2012M12, Included observations: 67

Chi-squared test statistics for lag exclusion:

Numbers in [ ] are p-values

\begin{tabular}{|c|c|c|c|c|c|c|}
\hline & DDEP & DDINT & DDUN & DW & DCPI & Joint \\
\hline Lag 1 & $\begin{array}{l}45.43697 \\
{[1.18 e-08]}\end{array}$ & $\begin{array}{c}25.97619 \\
{[9.02 e-05]}\end{array}$ & $\begin{array}{l}3.990262 \\
{[0.550819]}\end{array}$ & $\begin{array}{l}6.778725 \\
{[0.237624]}\end{array}$ & $\begin{array}{l}6.413052 \\
{[0.268075]}\end{array}$ & $\begin{array}{c}100.4776 \\
{[5.21 \mathrm{e}-11]}\end{array}$ \\
\hline Lag 2 & $\begin{array}{c}1.931222 \\
{[0.858578]}\end{array}$ & $\begin{array}{l}14.95388 \\
{[0.010561]}\end{array}$ & $\begin{array}{c}1.992175 \\
{[0.850227]}\end{array}$ & $\begin{array}{c}11.67631 \\
{[0.039503]}\end{array}$ & $\begin{array}{c}7.291410 \\
{[0.199854]}\end{array}$ & $\begin{array}{c}38.60728 \\
{[0.040315]}\end{array}$ \\
\hline Lag 3 & $\begin{array}{c}1.525299 \\
{[0.910132]}\end{array}$ & $\begin{array}{c}16.43782 \\
{[0.005699]}\end{array}$ & $\begin{array}{c}8.613920 \\
{[0.125490]}\end{array}$ & $\begin{array}{c}12.19772 \\
{[0.032177]}\end{array}$ & $\begin{array}{c}4.188455 \\
{[0.522614]}\end{array}$ & $\begin{array}{c}44.07298 \\
{[0.010643]}\end{array}$ \\
\hline df & (b) $* *$ & $\begin{array}{rr}5 & \\
& \text { Sou } \\
& \text { Note: } \\
* * & (\end{array}$ & $\begin{array}{l}5 \\
\text { : authorial } \\
\text { Numbers in } \\
\text { tes sionific }\end{array}$ & $\begin{array}{l}5 \\
\text { culations } \\
\text { are } p \text {-values }\end{array}$ & 5 & 25 \\
\hline
\end{tabular}

Moreover, the results in Table no. 3 show that we cannot reject the joint hypothesis that the coefficients of lags 1 are equal to zero. Thus, we have used for our study the lag 1 .

In such conditions, for the joint lag 1, the "Unrestricted Vector Autoregression"DDEP DDINT DDUN DW DCPI" may be written (see the estimates in Table no. 4):

$\operatorname{DDEP}=\mathrm{C}(1) * \operatorname{DDEP}(-1)+\mathrm{C}(2) * \operatorname{DDINT}(-1)+\mathrm{C}(3) * \mathrm{DCPI}(-1)+\mathrm{C}(4) * \mathrm{DDUN}(-1)+\mathrm{C}(5) * \mathrm{DW}(-1)$ $+\mathrm{C}(6)$

DDINT $=\mathrm{C}(7) * \mathrm{DDEP}(-1)+\mathrm{C}(8) * \mathrm{DDINT}(-1)+\mathrm{C}(9) * \mathrm{DCPI}(-1)+\mathrm{C}(10) * \mathrm{DDUN}(-1)+$ $\mathrm{C}(11) * \mathrm{DW}(-1)+\mathrm{C}(12)$

$\mathrm{DCPI}=\mathrm{C}(13) * \mathrm{DDEP}(-1)+\mathrm{C}(14) * \mathrm{DDINT}(-1)+\mathrm{C}(15) * \mathrm{DCPI}(-1)+\mathrm{C}(16) * \mathrm{DDUN}(-1)+$ $\mathrm{C}(17) * \mathrm{DW}(-1)+\mathrm{C}(18)$

DDUN $=\mathrm{C}(19) * \mathrm{DDEP}(-1)+\mathrm{C}(20) * \mathrm{DDINT}(-1)+\mathrm{C}(21) * \mathrm{DCPI}(-1)+\mathrm{C}(22) * \mathrm{DDUN}(-1)+$ $\mathrm{C}(23) * \mathrm{DW}(-1)+\mathrm{C}(24)$

$\mathrm{DW}=\mathrm{C}(25) * \mathrm{DDEP}(-1)+\mathrm{C}(26) * \mathrm{DDINT}(-1)+\mathrm{C}(27) * \mathrm{DCPI}(-1)+\mathrm{C}(28) * \mathrm{DDUN}(-1)+$ $\mathrm{C}(29) * \mathrm{DW}(-1)+\mathrm{C}(30)$

Table no. 5

Sample (adjusted): 2007M04 2012M12

Vector Autoregression Estimates

Included observations: 69 after adjustments

Standard errors in ( ), t-statistics in [ ] \& p-value in \{\}

\begin{tabular}{llllll}
\hline \hline & DDEP & DDINT & DCPI & DDUN & DW \\
\hline \hline DDEP(-1) & 0.813296 & -0.043497 & -0.022246 & -0.008950 & -0.123991 \\
& $(0.08307)$ & $(0.00826)$ & $(0.04167)$ & $(0.00986)$ & $(0.11649)$ \\
& {$[9.79057]$} & {$[-5.26792]$} & {$[-0.53390]$} & {$[-0.90812]$} & {$[-1.06443]$} \\
& $\{0.0000\}$ & $\{0.0000\}$ & $\{0.5938\}$ & $\{0.3645\}$ & $\{0.2879\}$ \\
& 3.531775 & 0.172018 & 0.561366 & 0.128337 & 0.139889
\end{tabular}


DDINT(-1)

\begin{tabular}{|c|c|c|c|c|c|}
\hline & $\begin{array}{l}(1.05209) \\
{[3.35690]} \\
\{0.0009\}\end{array}$ & $\begin{array}{l}(0.10458) \\
{[1.64491]} \\
\{0.1010\}\end{array}$ & $\begin{array}{l}(0.52772) \\
{[1.06377]} \\
\{0.2882\}\end{array}$ & $\begin{array}{l}(0.12482) \\
{[1.02821]} \\
\{0.3046\}\end{array}$ & $\begin{array}{l}(1.47532) \\
{[0.09482]} \\
\{0.9245\}\end{array}$ \\
\hline DCPI(-1) & $\begin{array}{c}-0.136298 \\
(0.24363) \\
{[-0.55945]} \\
\{0.5763\}\end{array}$ & $\begin{array}{c}-0.006861 \\
(0.02422) \\
{[-0.28330]} \\
\{0.7771\}\end{array}$ & $\begin{array}{l}0.254629 \\
(0.12220) \\
{[2.08369]} \\
\{0.0380\}\end{array}$ & $\begin{array}{c}-0.029382 \\
(0.02890) \\
{[-1.01658]} \\
\{0.3101\}\end{array}$ & $\begin{array}{l}0.213324 \\
(0.34163) \\
{[0.62442]} \\
\{0.5328\}\end{array}$ \\
\hline $\operatorname{DDUN}(-1)$ & $\begin{array}{l}0.652110 \\
(1.01811) \\
{[0.64051]} \\
\{0.5223\}\end{array}$ & $\begin{array}{l}0.016955 \\
(0.10120) \\
{[0.16755]} \\
\{0.8670\}\end{array}$ & $\begin{array}{l}0.027876 \\
(0.51067) \\
{[0.05459]} \\
\{0.9565\}\end{array}$ & $\begin{array}{c}-0.019422 \\
(0.12078) \\
{[-0.16080]} \\
\{0.8724\}\end{array}$ & $\begin{array}{c}-0.640040 \\
(1.42766) \\
{[-0.44831]} \\
\{0.6542\}\end{array}$ \\
\hline DW(-1) & $\begin{array}{l}0.001745 \\
(0.08827) \\
{[0.01977]} \\
\{0.5223\}\end{array}$ & $\begin{array}{c}-0.003455 \\
(0.00877) \\
{[-0.39377]} \\
\{0.8670\}\end{array}$ & $\begin{array}{l}-0.021873 \\
(0.04428) \\
{[-0.49400]} \\
\{0.9565\}\end{array}$ & $\begin{array}{l}0.016062 \\
(0.01047) \\
{[1.53377]} \\
\{0.1261\}\end{array}$ & $\begin{array}{l}0.064714 \\
(0.12378) \\
{[0.52280]} \\
\{0.6015\}\end{array}$ \\
\hline $\mathrm{C}$ & $\begin{array}{l}0.002679 \\
(0.00222) \\
{[1.20683]} \\
\{0.2284\}\end{array}$ & $\begin{array}{l}0.000674 \\
(0.00022) \\
{[3.05607]} \\
\{0.0024\}\end{array}$ & $\begin{array}{l}0.000630 \\
(0.00111) \\
{[0.56600]} \\
\{0.5718\}\end{array}$ & $\begin{array}{l}0.000108 \\
(0.00026) \\
{[0.40959]} \\
\{0.6824\}\end{array}$ & $\begin{array}{l}0.007369 \\
(0.00311) \\
{[2.36720]} \\
\{0.0185\}\end{array}$ \\
\hline $\begin{array}{l}\text { R-squared } \\
\text { Adj. R-squared } \\
\text { Sum sq. resids } \\
\text { S.E. equation } \\
\text { F-statistic } \\
\text { Log likelihood } \\
\text { Akaike AIC } \\
\text { Schwarz SC } \\
\text { Mean dependent } \\
\text { S.D. dependent }\end{array}$ & $\begin{array}{r}0.616431 \\
0.585990 \\
0.012176 \\
0.013902 \\
20.24941 \\
200.2569 \\
-5.630635 \\
-5.436365 \\
0.015076 \\
0.021606\end{array}$ & $\begin{array}{c}0.383793 \\
0.334887 \\
0.000120 \\
0.001382 \\
7.847666 \\
359.5520 \\
-10.24788 \\
-10.05361 \\
-5.80 \mathrm{E}-06 \\
0.001694\end{array}$ & $\begin{array}{c}0.111411 \\
0.040888 \\
0.003063 \\
0.006973 \\
1.579790 \\
247.8656 \\
-7.010596 \\
-6.816326 \\
0.000187 \\
0.007120\end{array}$ & $\begin{array}{c}0.096087 \\
0.024348 \\
0.000171 \\
0.001649 \\
1.339401 \\
347.3440 \\
-9.894028 \\
-9.699758 \\
7.10 \mathrm{E}-05 \\
0.001670\end{array}$ & $\begin{array}{r}0.038382 \\
-0.037937 \\
0.023942 \\
0.019494 \\
0.502919 \\
176.9285 \\
-4.954450 \\
-4.760180 \\
0.005885 \\
0.019135\end{array}$ \\
\hline \multicolumn{2}{|c|}{$\begin{array}{l}\text { Determinant resid covariance (dof adj.) } \\
\text { Determinant resid covariance } \\
\text { Log likelihood } \\
\text { Akaike information criterion } \\
\text { Schwarz criterion }\end{array}$} & $\begin{array}{r}1.65 \mathrm{E}-23 \\
1.05 \mathrm{E}-23 \\
1336.016 \\
-37.85555 \\
-36.88420\end{array}$ & & & \\
\hline
\end{tabular}

Source: authorial calculations

Note: Standard errors in ( ) \& t-statistics in [ ], p-value in \{\}

DDEP(-1) and DDINT(-1) are significant for DDEP and all together DDINT, DCPI, DDUN and DW influence the DDEP because p-value of VAR Granger Causality/Block Exogeneity Wald Tests for DDEP is $0.0137<0.05$. DDEP(-1) and a constant are significant for DDINT and all together DDEP, DCPI, DDUN and DW influence the DDINT because p-value of VAR Granger Causality/Block Exogeneity Wald Tests for DDEP is $0.000<0.05$. DCPI(-1) are significant for DCPI. The VAR stability condition check test shows that the VAR satisfies the stability condition (Table no. 5). 
Residuals tests are focused on VAR Residual Portmanteau Tests for Autocorrelations, Residual Serial Correlation LM Tests, and the White Test for Residual Heteroskedasticity. The results of the first two tests are illustrated in Tables no. 6 and no.7. Both tests show that the null hypothesis of no serial autocorrelation in residuals cannot be rejected. The "unit root tests" of residuals suggest the same conclusions (Table no. 8). Cross-sections represent the number of residual series generated by VAR unrestricted equations (in our case 5 equations). Even if the heteroskedasticity is more relevant for the analysis of cross-section data than for time-series data (Vogelvang (2005)), the White Test has been used. The results are illustrated in Table no. 9, and they indicate that the variance of the disturbance term is constant (the null cannot be rejected) ${ }^{4}$. The "Unrestricted Vector Autoregression DDEP DDINT DCPI DDUN DW" model may be considered representative and stable.

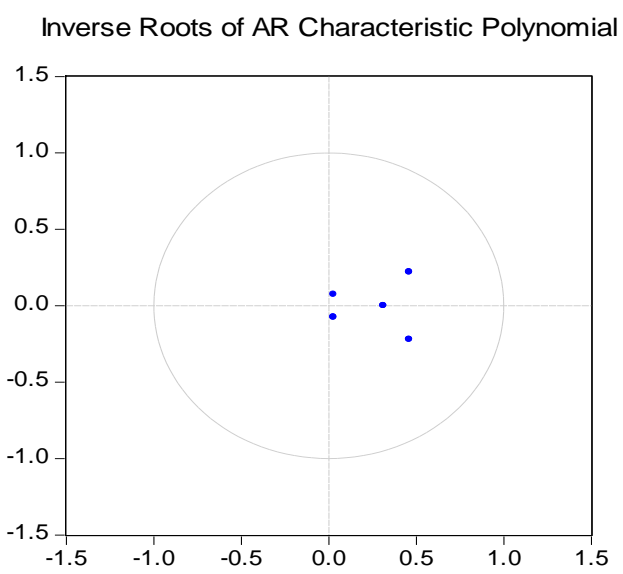

Figure no. 1 - Inverse Roots of AR Characteristic Polynomial

Source: authorial calculations

\section{Findings and Results}

In Romania, the evolution of household deposits was positive in real terms in the second half of 2011, after the contraction recorded in the last four quarters, on the back of:

1. maintaining attractive levels of interest rates offered by banks for deposits in national currency; 2. a relative improvement dynamics of the Monthly net Wages, with households' preference for making precautionary savings. (see Table no. 11).

\section{Household deposits in Romania}

Table no. 6

\begin{tabular}{|l|l|l|l|l|l|l|}
\hline & $12 / 2008$ & $12 / 2009$ & $12 / 2010$ & $12 / 2011$ & $12 / 2012$ & $08 / 2013$ \\
\hline $\begin{array}{l}\text { Household } \\
\text { deposits }\end{array}$ & 24.4 & 26.7 & 27.0 & 28.7 & 30.2 & 31.8 \\
\hline
\end{tabular}

Source: Romanian National Bank - Financial Stability Report, 2013

The domestic deposits continues to provide most of the funding needs of the banking assets in Romania. Since 2010, the population is maintained as a most important creditor of the banking sector. About two-thirds of the deposits are attracted by the population; this provides greater stability in terms of the degree of permanence of these sources. The share of household deposits in

\footnotetext{
${ }^{4}$ See Appendix 1
} 
the balance sheet liabilities of the Romanian banks is relatively high compared with the structure of financing sources of credit institutions in the euro area (in the euro area non-bank customers accumulate around 30 percent of total liabilities). After the maturity criteria, there was a consolidation of investments by household's term exceeding 1 year.

The annual growth rate of household deposits was recorded a downward trend but still, the values remained positive (from $6.9 \%$ in $08 / 2012$ to $1.7 \%$ in $08 / 2013$, real terms).

The annual growth rate of household deposits in national currency was limited (from $6.4 \%$ in $08 / 2012$ to $-0.8 \%$ in $08 / 2013$, real terms).

These changes reflect:

1. the significant decline in the deposit interest rates on national currency and foreign currency, operated by banks;

2. the reducing of the available amount for saving in the context of lower average Monthly net Wages growth;

3. the statistical effect of increasing the annual inflation rate.

In our study we analyzed two types of results: impulse response function and variance decomposition. Based on the model proposed in this study, we can perform impulse response functions, configured bellow, combined with the $95 \%$ confidence intervals. Firstly, we analyzed an impulse response function that traces the effect of a one-time shock to one of the shocks (innovations) on current and future values of the endogenous variables (Figure no. 2). Second, we studied the asymmetric generalized responses for original data (Figure no. 3). The continuous blue line represents the impulse response function and the dotted red lines delimit the confidence intervals.

It is observed from the figure no. 2 that, following a positive shock transmitted though the variation of population deposits, deposits exhibits an immediate rise above the long-run base at $\mathrm{t}=1$, exhibit a declining trend $1<\mathrm{t}<7$ period which remains above the long-run base, and exhibit constant to zero for $\mathrm{t}>7$. The deposits (DDEP) response on a deposits (DDEP) shock is positive, with maximum amplitude in the first month, tending towards zero in the months 7 to 12 . This means that especially starting from the seventh month, until the end of the year there are other factors which influence the evolution of deposits: their maturity, their term, as well as other various factors, which are not economic in nature (psychological factors, behavioral - for instance the leaves in the summer months may influence the evolution of deposits). We find that a $1 \%$ positive shock in deposits is able to generate a positive response of DDEP by $1.4 \%$.

Figure no. 2 shows that, following a positive shock transmitted through the variation of interest rate channel, the variation of deposits exhibit a significant rise above the long-run base for 1 to 2 periods, for 2 to 3 period remain constant and for $3<t<8$ period exhibit a declining trend, tending towards zero in the months 8 to 12 . The deposits (DDEP) response on a interest rate (DDINT) shock is positive with maximum amplitude in the first and second months, tending towards zero in the months 8 to 12 . Between 1-3 months, after DDINT shock exhibit, the positive response of the deposits is statistically significantly. These results show us that in the first half of the year the evolution of the interest rate influences the volume of deposits. The situation is not the same for the second half of the year. The saving pattern differs fundamentally from the first half of the year, due to non-economic factors which influence this behavior. $1 \%$ positive shock in interest rate is able to generate a positive response of DDEP by $0.8 \%$. 
Response to Cholesky One S.D. Innovations \pm 2 S.E.
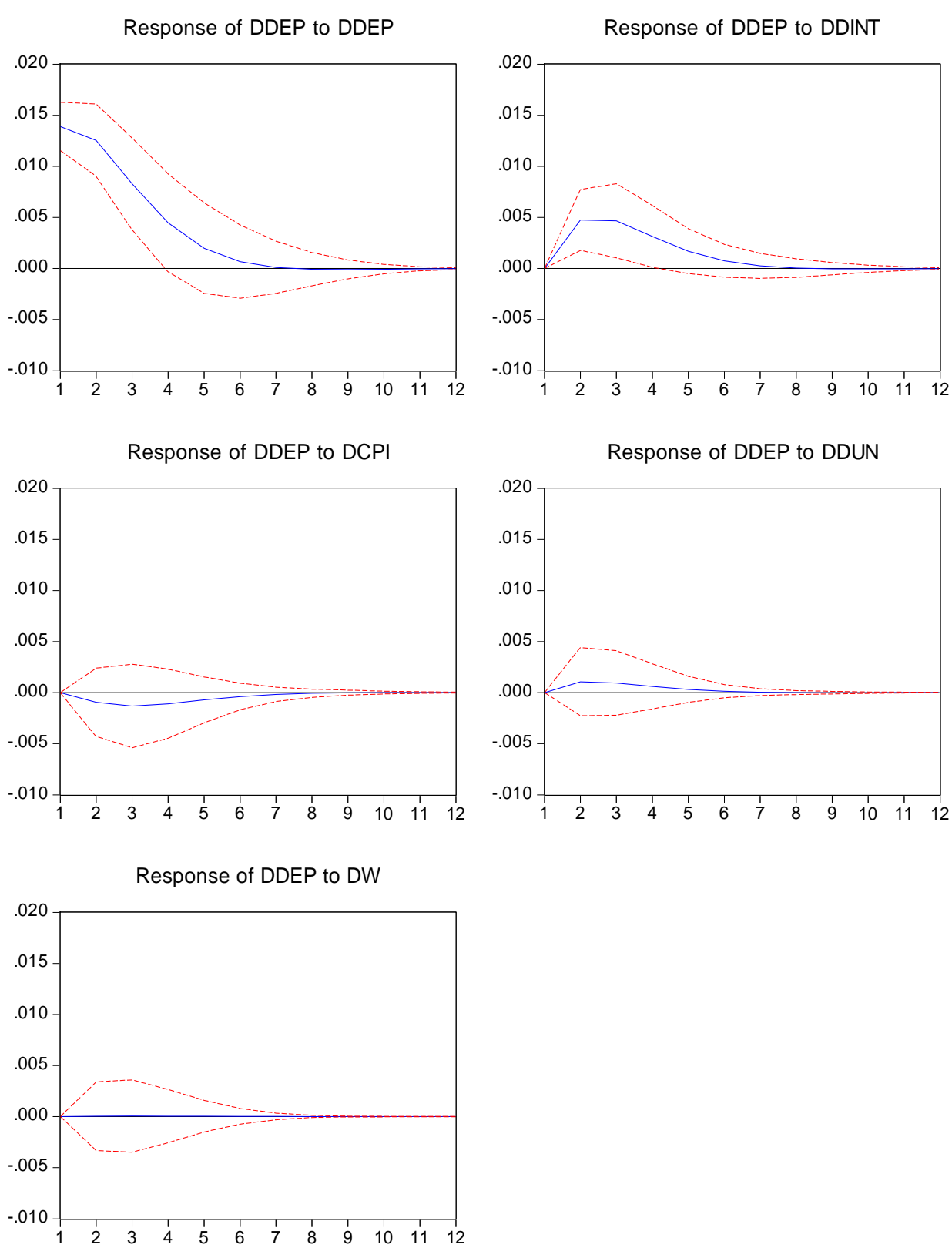

Figure no. 2 - Impulse response function one standard deviation innovations

Source: authorial calculations

DCPI inflation shocks goes into a negative answer DDEP deposit amount, but not significantly different from zero, in particular in the range of 6-12 months. $1 \%$ positive shock in DCPI is able to generate a negative response of DDEP by $-0.5 \%$.

DDUN unemployment shocks cause a positive reaction in the DDEP, upward in the months 1 to 2 and downward within the range 2-6. Response is not significantly different from zero in the range 6-12. $1 \%$ positive shock in DDUN is able to generate a positive response of DDEP by $0.4 \%$.

DW wages shocks generate response without statistical significance in the deposits DDEP. 
Accumulated Response to Cholesky One S.D. Innovations \pm 2 S.E.

Accumulated Response of DDEP to DDEP Accumulated Response of DDEP to DDINT
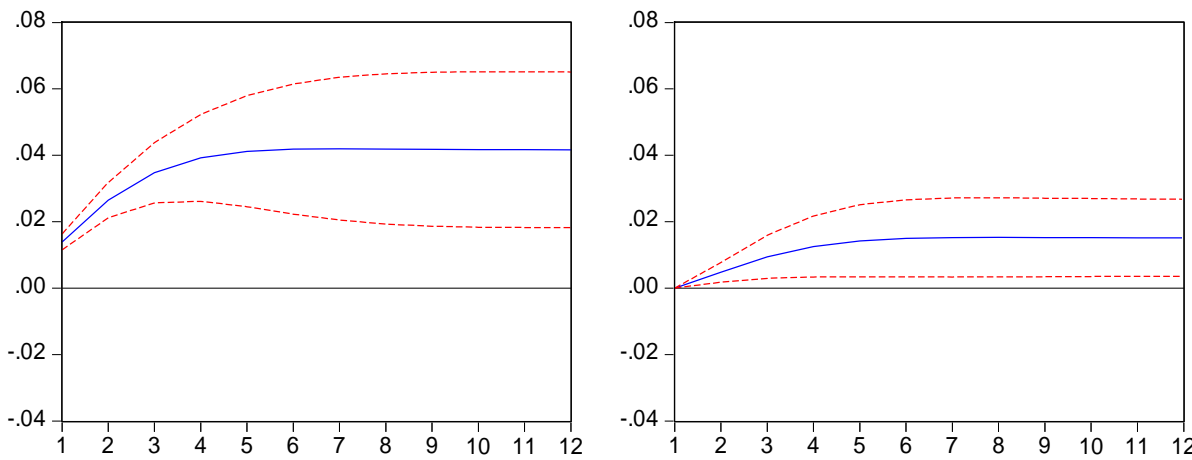

Accumulated Response of DDEP to DCPI

Accumulated Response of DDEP to DDUN
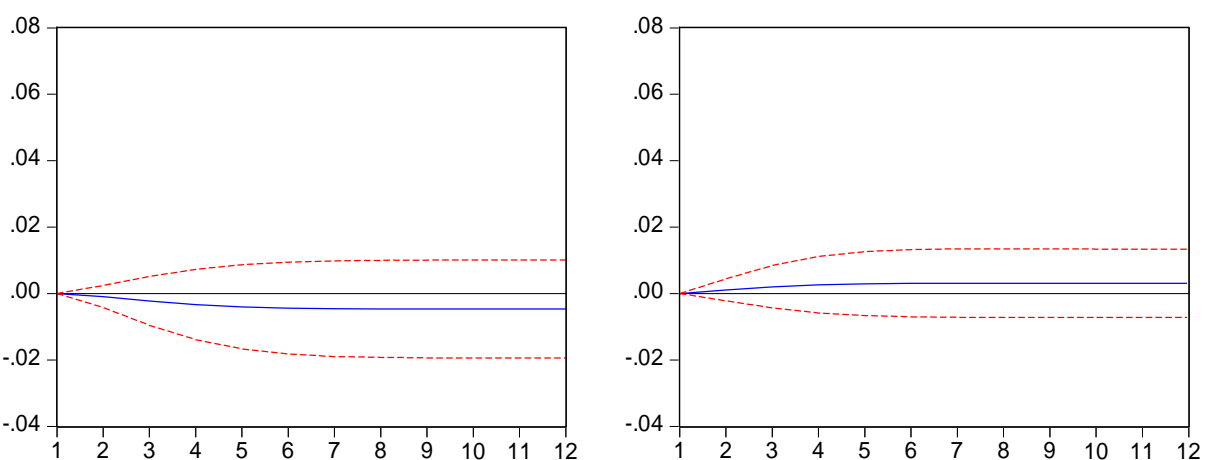

Accumulated Response of DDEP to DW

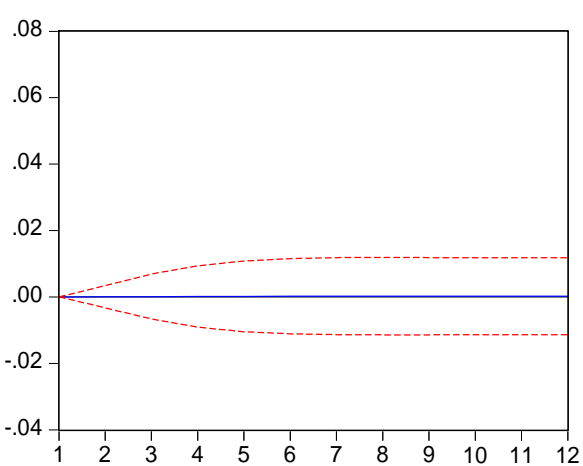

Figure no. 3 - Generalized impulse response function

Source: authorial calculations

Notice how, according to the figure no. 3, following a $1 \%$ positive shock transmitted through the variation of population deposits (characterized by an exogenous, unanticipated temporary increase in the population deposits), deposits exhibits an immediate rise above the longrun between $\mathrm{t}=1$ month and $\mathrm{t}=4$ month, from $1.8 \%$ to $4 \%$. The effect is statistically significant right from the first month. During $4<\mathrm{t}<12$ periods, deposits exhibit constant in increasing, around $4 \%$. The deposits (DDEP) response on deposits' shock (DDEP) is positive and statistically significant, with maximum amplitude in the first period and tending to be stationary to its previous value in the fourth to twelfth months.

Following a $1 \%$ positive shock transmitted through the variation of interest rate channel (DDINT), the variation of deposits (DDEP) exhibits a rise above the long-run base for first to fourth 
month (from 0 to $1,5 \%$ ) and for $4<\mathrm{t}<12$ month exhibit a linear stationary positive response, around $1,5 \%$. These results show us that in the first four months of the year, the evolution of the interest rate significantly influences the volume of deposits. Also, we found impulse response for the second half of the year, but the situation is stationary.

A $+1 \%$ inflationary shock (DCPI) conduct to a negative response in deposits (DDEP), that exhibit a declining trend which remains above the long-run base, not significantly different of zero. Response of deposits (DDEP) to the $+1 \%$ shock in unemployment rate (DDUN) is positive, but not significantly different of zero. Response of deposits (DDEP) to the $+1 \%$ shock in monthly net wages in the economy (DDUN) tends to zero.

Variance decompositions separate the variation in an endogenous variable into some component shocks. Thus variance decompositions provide information about the relative importance of each random innovation. We seek to examine the relative importance of deposit variation of these five exogenous variables. The decompositions of deposits variations is given in Table no. $10^{5}$.

Variance decomposition suggests how important is each exogenous shock in the explaining of the variables' dependence and explain what percent from the deposits volume is justified by the shock of each other variable. We can observe the overwhelming influence of the own deposits (DDEP) shocks, during all the analyzed intervals, descending tendency during the first and third period, up to $89,56 \%$ and subsequent during the fourth and tenth interval, approximately the same percentage $87 \%$. Among the variables of the model, only the interest rate of the deposits presents the relative importance in explaining the shocks of volume of deposits, according to obtaining values between 5 and $11 \%$. Another three studied variables have subunit values from decomposition and this denotes the insignificant relative importance in explaining the shocks that affect the volume of deposits.

\section{Conclusions}

Banking customers can distribute their savings across multiple products of banks or another financial institutions. Customers' attitude in choice the deposits as a savings method depends on varied factors, that can be divided in endogenous and exogenous. Starting with the assumption that the banking customers' perceptions were dramatically modified in the last years, the paper provides evidence of the banking customers' behavior and highlights the relationship between customers' deposits and four exogenous factors - the interest rate on the deposits set up in banks by householders, the unemployment rate, the monthly net wages in the economy and the consumer price index.

This study presents a novel approach in the existing gap of the national literature, that is completed with present econometrical research, using unrestricted Vector Autoregression Model (VAR) on Romanian banking system, which covers the period January 2007 - December 2012. After briefly reviewing the actual knowledge in the area, the paper identified the variables that can influence the customers 'deposits. We evaluates the effects of the different shocks on the VAR DDEP (deposits made with active banks in Romania by the population's householders) system's variables, considering that each variable is influenced by the own impulse and also it is influenced by the impulses of the other variables. Studied variables present features that permit VAR approach, through we aim the following types of results: impulse response function and variance decomposition.

As the results show, the five analyzed factors (DDEP; DDINT; DCPI; DDUN; DW) could influence the behavior of households on bank deposits, but deposits itself and interest rate stronger influence evolution of deposits. We find that: a $1 \%$ positive shock in deposits is able to generate a

\footnotetext{
${ }^{5}$ See Appendix 2
} 
positive response of DDEP by $1.4 \%$, a $1 \%$ positive shock in interest rate is able to generate a positive response of DDEP by $0.8 \%$, a $1 \%$ positive shock in DCPI is able to generate a negative response of DDEP by $-0.5 \%$, a $1 \%$ positive shock in DDUN is able to generate a positive response of DDEP by $0.4 \%$ and DW wages shocks generate response without statistical significance in the deposits DDEP. This means that there are other various factors which influence the evolution of deposits: their maturity, their term, psychological factors, behavioral (for instance the leaves in the summer months may influence the evolution of deposits). From a bank point of view, in this context, there is not only exogenous variables that influence the behavior of households on bank deposits. There are a lot of endogenous variables that influence the behavior and these will be studied in future works.

Studying Accumulated Response we find that: a positive impulse in DDEP determines a flat increasing of DDEP in the first part of the year. Then, the level of this variable is maintained at the same value until to the end of the year. Also, a positive impulse in DDINT determines a flat increasing of DDEP until the fourth month and we note that the increase is less than the first case (DDEP to DDEP). The other three exogenous variables (DCPI, DUN; DW) had insignificant influences to DDEP (for example: a positive impulse in DW tends to zero DDEP). This reaction shows that, in the case of Romanian banking sector, there are a lot of other factors that can influence deposits.

Limits of this research consist in the VAR approach of each variable, that is regressed against the same number of lags of every variable. In other words, VAR lag specifications are symmetrical. Unfortunately, VARs often estimate a large number of statistically insignificant coefficients, and therefore the impulse responses and variance decompositions constructed from the reduced-form coefficients will often be imprecisely determined.

From the analysis of the shocks on the each studied variable, we found proves that suggest the existence of another factors that influence the banking customers' behavior, referring to the deposits' maturity, their term, as well as other various factors, which are not economic in nature (psychological factors, behavioral - for instance the leaves in the summer months may influence the evolution of deposits). These findings open the ways to further research, that may aim intrinsic psychological behavioral analyzing models referring to banking customers.

The health of the banking system depends on financial macroeconomic stability in each country. We have analyzed some of macroeconomic indicators (the deposits made with active Banks in Romania by the Population's householders; the interest rate on the deposits set up in Banks by householders; Consumer price index; Unemployment rate and Monthly Net Wages in the economy) and tried to detect the correlation between them.

To preserve and strengthen financial macro stability is necessary:

$\checkmark$ to continue the structural reforms in the economy;

$\checkmark$ to improve the constraints related to the labor market;

$\checkmark$ to improve the absorption of European funds;

$\checkmark$ to grow the role of innovation in economic development. 
APPENDIX 1

Table no. 7

Roots of Characteristic Polynomial

VAR stability condition check test

Endogenous variables: DDEP DDINT DDUN DW DCPI

Exogenous variables: $\mathrm{C}$

Lag specification: 11

Date: 07/29/13 Time: 16:33

\begin{tabular}{lc}
\hline \hline Root & Modulus \\
\hline \hline $0.459080-0.221323 \mathrm{i}$ & 0.509646 \\
$0.459080+0.221323 \mathrm{i}$ & 0.509646 \\
0.312219 & 0.312219 \\
$0.027427-0.074885 \mathrm{i}$ & 0.079750 \\
$0.027427+0.074885 \mathrm{i}$ & 0.079750 \\
\hline \hline
\end{tabular}

Source: authorial calculations

No root lies outside the unit circle.

VAR satisfies the stability condition.

VAR Residual Portmanteau Tests for Autocorrelations

Table no. 8

Null Hypothesis: no residual autocorrelations up to lag $\mathrm{h}$

Date: 08/01/13 Time: 09:49

Sample: 2007M01 2012M12

Included observations: 69

\begin{tabular}{llllll}
\hline \hline Lags & Q-Stat & Prob. & Adj Q-Stat & Prob. & df \\
\hline \hline 1 & 11.39174 & NA* & 11.55927 & NA* & NA* \\
2 & 39.10697 & 0.0359 & 40.10182 & 0.0285 & 25 \\
3 & 69.79809 & 0.0336 & 72.18798 & 0.0217 & 50 \\
4 & 89.56269 & 0.1203 & 93.16887 & 0.0761 & 75 \\
5 & 113.0720 & 0.1753 & 118.5149 & 0.0998 & 100 \\
6 & 133.9556 & 0.2758 & 141.3874 & 0.1501 & 125 \\
7 & 142.9045 & 0.6472 & 151.3466 & 0.4538 & 150 \\
8 & 172.0935 & 0.5480 & 184.3636 & 0.2990 & 175 \\
9 & 203.5175 & 0.4176 & 220.5013 & 0.1527 & 200 \\
10 & 219.1702 & 0.5971 & 238.8070 & 0.2517 & 225 \\
\hline \hline
\end{tabular}

Source: authorial calculations

*The test is valid only for lags larger than the VAR lag order.

$\mathrm{df}$ is degrees of freedom for (approximate) chi-square distribution 
VAR Residual Serial Correlation LM Tests

Table no. 9

Null Hypothesis: no serial correlation at lag order $\mathrm{h}$

Date: 08/01/13 Time: 09:51

Sample: 2007M01 2012M12

Included observations: 69

\begin{tabular}{lll}
\hline \hline Lags & LM-Stat & Prob \\
\hline \hline 1 & 33.27286 & 0.1244 \\
2 & 33.87880 & 0.1105 \\
3 & 31.37374 & 0.1769 \\
4 & 19.58279 & 0.7684 \\
5 & 22.22775 & 0.6226 \\
6 & 21.46938 & 0.6662 \\
7 & 8.312517 & 0.9993 \\
8 & 29.53901 & 0.2420 \\
9 & 34.05454 & 0.1067 \\
10 & 16.36835 & 0.9034 \\
\hline \hline
\end{tabular}

Source: authorial calculations

Probs from chi-square with $25 \mathrm{df}$.

The Unit Root Tests of VAR residuals

\begin{tabular}{lcccc} 
Method & Statistic & Prob.** & $\begin{array}{c}\text { Cross- } \\
\text { sections }\end{array}$ & Obs \\
\hline Null: Unit root (assumes common unit root process) & & & 337 \\
\hline Levin, Lin \& Chu t* & -18.0117 & 0.0000 & 5 & \\
Null: Unit root (assumes individual unit root process) & & & 337 \\
\hline Im, Pesaran and Shin W-stat & -16.6886 & 0.0000 & 5 & 337 \\
ADF - Fisher Chi-square & 151.017 & 0.0000 & 5 & 340 \\
PP - Fisher Chi-square & 139.024 & 0.0000 & 5 & \\
\hline \hline
\end{tabular}

Source: authorial calculations

** Probabilities for Fisher tests are computed using an asymptotic Chi

-square distribution. All other tests assume asymptotic normality.

VAR Residual Heteroskedasticity Tests: No Cross Terms

Table no. 11

Sample: 2007M01 2012M12

(only levels and squares)

Included observations: 69

\begin{tabular}{lll}
\hline \hline \multicolumn{1}{c}{ Joint test: } & & \\
\hline \hline Chi-sq & df & Prob. \\
\hline \hline 162.0949 & 150 & 0.2362 \\
\hline \hline
\end{tabular}

Source: authorial calculations 


\section{APPENDIX 2}

Table no. 12

Variance decompositions of DDEP

\begin{tabular}{lllllll}
\hline \hline Period & S.E. & DDEP & DDINT & DCPI & DDUN & DW \\
\hline \hline 1 & 0.013902 & 100.0000 & 0.000000 & 0.000000 & 0.000000 & 0.000000 \\
2 & 0.019373 & 93.46295 & 5.995019 & 0.236587 & 0.305150 & 0.000294 \\
3 & 0.021641 & 89.56492 & 9.446897 & 0.554847 & 0.432499 & 0.000837 \\
4 & 0.022352 & 87.94247 & 10.81969 & 0.757793 & 0.478873 & 0.001180 \\
5 & 0.022517 & 87.43524 & 11.22621 & 0.845297 & 0.491837 & 0.001410 \\
6 & 0.022543 & 87.32208 & 11.31021 & 0.871848 & 0.494340 & 0.001519 \\
7 & 0.022545 & 87.30633 & 11.32014 & 0.877381 & 0.494597 & 0.001556 \\
8 & 0.022545 & 87.30564 & 11.32015 & 0.878048 & 0.494590 & 0.001565 \\
9 & 0.022546 & 87.30568 & 11.32012 & 0.878051 & 0.494590 & 0.001566 \\
10 & 0.022546 & 87.30553 & 11.32026 & 0.878046 & 0.494596 & 0.001566 \\
11 & 0.022546 & 87.30542 & 11.32036 & 0.878054 & 0.494599 & 0.001566 \\
12 & 0.022546 & 87.30539 & 11.32039 & 0.878060 & 0.494600 & 0.001566 \\
\hline \hline
\end{tabular}

Source: authorial calculations

Cholesky Ordering: DDEP DDINT DCPI DDUN DW

\section{References}

1. Bichi C., 2002. Romanian Deposit Guarantee Scheme and the requirements of the Acquis Communautaire, Romanian Journal of European Affairs, 4(2), pp. 66-78

2. Ciurila N., 2007. Estimating the Exchange Rate Pass through into Inflation in a Vector Autoregressive Framework, The Journal of the Faculty of Economics - Economic Science Series, Vol. 2, pp. 234-238

3. Cocriș V., Nucu A. E., 2013. Monetary and financial stability: empirical evidence form Central and Eastern European countries, Baltic Journal of Economics, No. 13 (1), pp. 75-98

4. Cromwell J. B., Labys W., Terraza M., 1994. Univariate Tests for Time Series Models, Quantitative Applications in the Social Sciences, Sage University Paper

5. Gujarati D. N., 2001. Basic econometrics (4th ed)., New York: The McGraw-Hill Companies Inc.

6. Holod D., Lewis H. F., 2011. Resolving the deposit dilemma: A new DEA bank efficiency model, Journal of Banking \& Finance, 35, pp. 2801-2810

7. Mutaşcu M. I., Dănuleţiu D. C., 2011. Taxes and economic growth in Romania. A VAR approach, Annales Universitatis Apulensis Series Oeconomica, 13(1), pp. 94-105

8. Mutașcu M., Fleischer A. M., 2011. Economic Growth and Globalization in Romania, World Applied Sciences Journal, No, 12(10), pp. 1691-1697

9. Nelson C. R., Plosser C. R., 1982. Trends and random walks in macroeconmic time series: Some evidence and implications, Journal of Monetary Economics, 10(2), pp. 139-162

10. Nyström K., 2008. On deposit volumes and the valuation of non-maturing liabilities, Journal of Economic Dynamics \& Control, 32, pp. 709-756

11. O'Brien J. M., 2000. Estimating the value and interest rate risk of interest-bearing transactions deposits, Working Paper, [online] Available at:

http://ideas.repec.org/p/fip/fedgfe/2000-53.html [Accessed 15 Sep. 2013] 
12. Pecican E. Ș., 2010. Forecasting Based on Open VAR Model, Romanian Journal of Economic Forecasting, No. 1, pp. 59-69

13. Roșoiu A., Roșoiu I., 2014. Monetary Policy Transmission Mechanism in Romania - a Bayesian VAR Approach, International Journal of Economic Practices and Theories, Vol. 4, No. 2, pp. 199-205

14. Sims C. A., 1980. Macroeconomics and reality, Econometrica, 48 (1), pp. 1-48

15. Spulbăr C., Nițoi M., 2013. Monetary Policy Transmission Mechanism in Romania over the period 2001 to 2012: A BVAR Analysis, Scientific Annals of the Alexandru Ioan Cuza University of Iași Economic Sciences, No. 60(2), pp. 387-398

16. Vogelvang B., 2005. Econometrics. Theory and Applications with EViews, Pearson Education Limited

17. *** National Bank of Romania, 2012. Stability Financial Report [online]. Available at: http://www.bnr.ro/Regular-publications-2504.aspx [Accessed 15 Sep. 2013]

18. *** Government Ordinance no. 39/1996 on establishing and functioning of the Bank Deposit Guarantee Fund in the banking system, republished in Official Gazette no. 587/2010

19. *** Government Ordinance no. $1 / 2012$ on amending and suplementing some parts of legislation in the field of credit institutions published in Official Gazette no. 41/2012 